\title{
Predictors of Helicobacter pylori infectivity, Using Stool Antigen Test in Al- Qurna
}

\author{
Talib Kadhim Aggar (M.B.Ch.B., FICMS \\ Basrah, Iraq College of Medicine, University of Basrah Lecturer, Department of Medicine \\ Rafid AJ Mohammed. (M.B.Ch.B., C.A.B.S. MRCS) \\ Basrah, Iraq College of Medicine, University of Basrah Lecturer, Department of surgery \\ Abddulhameed Majeed (M.B.Ch. B CABM) \\ Alsadr teaching hospital, Basrah, Iraq Head of Department of Medicine
}

\section{Abstract}

Aim: To identify predictors of Helicobacter pylori ( $\mathrm{H}$ pylori) infectivity, Using stool antigen test with its correlations to epigastric abdominal pain and other gastrointestinal symptoms.

Patients \&methods: Patients from Al Qurna presented to private clinic with epigastric abdominal pain each of them has been screened for $\mathrm{H}$ pylori via stool antigen test, after evaluations of other causes of abdominal pain. Data analysis was carried out using SPSS version-15

Results: a total of 254 patients 142 $(55.9 \%)$ were males and $112(44.1 \%)$ were females were studied. H pylori stool antigen was positive in $69(27.2 \%)$ and negative in 185 $(72.8 \%)$ of the studied patients. Gastrointestinal symptoms that were observed included weight loss, loss of appetite (3.6\%), heart burn (60.6\%), vomiting (28.3\%), diarrhea (7.1\%), constipation (15.4\%) and abdomen distension $(24 \%)$. In $59.3 \%$ of the $\mathrm{H}$. pylori antigen positive cases, the duration of epigastric pain was of $>$ two weeks. Conclusions: logistic regression analysis indicated that epigastric abdominal pain of > two weeks and loss of appetite were two significant predictors of H. Pylori infection. 


\section{Introduction}

Isolation of $\mathrm{H}$. pylori in $1983 \mathrm{had}$

revolutionized the history of Gastrointestinal (GIT) medicine. ${ }^{(\mathbf{1})}$ H. pylori plays a vital role in the aetiology of gastritis especially active antral gastritis, and accounts for 90\% of duodenal ulcers and $70 \%$ gastric ulcers. ${ }^{(2)}$ It also plays a role in the development of gastric mucosa-associated lymphoid tissue (MALT), lymphoma and gastric adenocarcinoma ${ }^{(3)}$. Thus the prevalence of this microorganism is a determinant of the risk of peptic ulcer and related lesions. In a study reported a prevalence rate of $55.8 \%$ among university students. ${ }^{(4)}$ The bacteria can be cultivated from stool, vomitus and saliva in

$$
\text { normal individual }{ }^{(5)} \text {. }
$$

In niebouring countries as Saudi Arabia

the prevalence of $\mathrm{H}$. pylori infection was detected in $61 \%$ in asymptomatic subject ${ }^{(6)}$ and a comparable result was found in Turkey

$$
\text { also }(56.6 \%){ }^{(7)}
$$

Amazing seroprevalence rate of $\mathrm{H}$

pylori in asymptomatic subject seen in Bangladesh (92\%).The majority of infected subjects are asymptomatic and clinical disease is only observed in minority. (2)

The methods currently used for detection of $\mathrm{H}$. pylori in man include culture of organism from mucosal biopsy or using isotope based urea breath test ${ }^{(2)}$ or H. pylori stool antigen test (HPSA T), which is cheap, sensitive and specific in $>95 \%$ of patients ${ }^{(2)}$ (HPSA T) is useful for follow up after detecting and eradication current infection. ${ }^{(8)}$

The current study was designed to determine the relationship between $\mathrm{H}$. pylori stool antigen test, asindex of infectivity and its correlation with various epigastric pain and other GIT symptoms (weight loss, loss of appetite, heart burn and regurgitation, vomiting, diarrhea, constipation and abdomen distension. (2)

Other variables that may potentially cause GIT diseases including smoking, drinking of alcohol, using drugs like corticosteroids or non steroidal anti inflammatory drugs (NSAID) were also explored. 


\section{Patients and methods}

This is a two years' study involving recruitment of patients attended a clinic from October 2012 until January 2014 in Al Qurna district $74 \mathrm{~km}$ northwest of Basrah. All patients presented with epigastric abdominal pain were included. Each patient was evaluated for age, gender, GIT symptoms, history of smoking, drinking alcohol and corticosteroids treatment and NSAID use. Investigations were done after clinical examination included abdominal ultrasound for most of patients. Fresh stool sample received from each patient and analyzed for detection of H. pylori antigen. Rapid diagnostic test (chromogenic test) was used to detect Helicobacter pylori in stool samples from (ABON company, China). The principle of this technique depends on presence of antigen (bacterium $\mathrm{H}$. pylori) and antibody from the kit. Stool sample emulsion was put on the kit strip and reacts with antibody to make a color result. The appearance of one red line was regarded as negative and two red lines regarded as positive result (under company instructions).
A brief description of symptom and other variables studied was as follows:

Weight loss: The loss of $4.5 \mathrm{~kg}$ or $>5 \%$ of body weight over a period of 6-12 months.

Loss of appetite: Reduced desire for eating for at least three days ${ }^{(9)}$

Heart burn: The presence of retrosternal burning pain. ${ }^{(10}$

Regurgitations: The presence of sour or bitter tasting fluid coming into mouth. ${ }^{(10)}$ Vomiting defined as forceful expulsion of gastric content.

Diarrhea: Passage of frequent stools $>$ three bowel motions per day or change in consistency of the stool. ${ }^{(11)}$

Constipation was defined as passage of less than three bowel motions per week or passage of hard stool or stool that is difficult to be evacuated. ${ }^{(11)}$

Abdominal distension: Gaseous distension on ultrasonic examination.

Smoking was defined as a history of smoking at least one cigarette a week. ${ }^{(11)}$ Drinking of alcohol was sorted as any regular intake of alcohol 
Corticosteroid treatment is defined as any recent or concurrent history of oral or injectable intake of corticosteroids like prednisolone, dexamethasone, betamethasone or hydrocortisone.

\section{Non steroidal anti inflammatory drugs}

(NSAIDs) use sorted as recent or old use of the available types like diclofenac, ibuprofen, mefenamic acid, indomethacin, piroxicam or

$$
\text { aspirin. }
$$

\section{Positive ultrasound examination described}

any abdominal pathology like gall bladder, liver, intestinal, pancreatic or peritoneal diseases.

Statistical analyses were done using Statistical Package for Social Science(SPSS) for windows version 15 , logistic regression analysis was done to identify the independent predictors which significantly associated with $\mathrm{H}$. pylori infection a $\mathrm{p}$ value of $<0.05$ was considered significant.

\section{Results}

Of the 254 patients with epigastric abdominal pain, $142(55.9 \%)$ were males and $112(44.1 \%)$ were females. Male: female ratio was 1.26: 1 . The mean age was $34.2 \pm 11.7$ years (Males=
$24.3 \pm 10.7$, females $=34.1 \pm 13.0)$. The test for H. pylori stool antigen (HPSA) was positive in $69(27.2 \%)$ patients and negative in $185(72.8 \%)$ of the patients. Table 1 shows the distribution of patients according to various symptoms and the percentage of patients with $H$ pylori positive or negative results... The majority of patients with epigastric pain presented with heart burn (60.6\%). The other symptoms with relatively higher frequency were vomiting, constipation and feeling of distension. Symptoms with lower frequency were weight loss, loss of appetite, regurgitation and diarrhoea. Smoking was reported by 16.1 $\%$ while alcohol was reported by only two patients. Ultransound examination revealed positive evidence of other pathologies in 7 $(2.8 \%)$ of the patients only. History of NSAID intake was reported by $6.7 \%$ and corticosteroids intake was reported by one patient only. In the Univariate analysis, only three variables were significantly associated with positive $\mathrm{H}$ pylori results $(\mathrm{P}<0.05)$. These included age, duration of epigastric pain and loss of appetite. All the others did not show significant association with $H$ pylori positivity. 


\section{Thi-Qar Medical Journal (TQMJ): Vol (11) No (1)2016 utjmed@utq.edu.iq}

In the logistic regression analysis, age

lost its effect as predictor of $\mathrm{H}$ pylori positivity

but duration of epigastric pain and loss of appetite remained strong independent predictors as shown in (Table 2).

Table (1): Results of $H$ pylori stool antigen in relation to selected patient characteristics

\begin{tabular}{|c|c|c|c|c|c|}
\hline \multirow{2}{*}{$\begin{array}{r}\text { Characteristics } \\
\text { Gender } \\
\text { Female } \\
\text { Male } \\
\text { Total }\end{array}$} & \multicolumn{2}{|c|}{$\begin{array}{r}\text { Patients studied } \\
\text { No. } \% \text { out of total }\end{array}$} & \multicolumn{2}{|c|}{$\begin{array}{c}\text { H pylori positive } \\
\text { No. } \%\end{array}$} & P value* \\
\hline & $\begin{array}{c}112 \\
142 \\
254\end{array}$ & $\begin{array}{c}44.1 \\
55.9 \\
100.0\end{array}$ & $38^{31}$ & $\begin{array}{c}26.8 \\
100.0\end{array}$ & 0.491 \\
\hline $\begin{array}{r}\text { Age } \\
<20 \\
20-29 \\
30-39 \\
40-49 \\
50-59 \\
60+\end{array}$ & $\begin{array}{l}19 \\
81 \\
75 \\
44 \\
24 \\
11\end{array}$ & $\begin{array}{r}7.5 \\
31.9 \\
29.5 \\
17.3 \\
9.4 \\
4.3\end{array}$ & $\begin{array}{lr}9 & \\
17 & \\
17 & \\
& 15 \\
& 10 \\
1 & \end{array}$ & 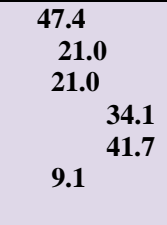 & 0.044 \\
\hline $\begin{array}{r}\text { Duration of pain } \\
\leq 2 \text { weeks } \\
>2 \text { weeks } \\
\text { Total }\end{array}$ & $\begin{array}{c}100 \\
146 \\
246\end{array}$ & $\begin{array}{r}40.7 \\
59.3 \\
100.0\end{array}$ & $\begin{array}{l}19 \\
47 \\
66\end{array}$ & $\begin{array}{l}19.0 \\
32.2 \\
26.8\end{array}$ & 0.008 \\
\hline \begin{tabular}{cr}
\multicolumn{2}{c}{ Weight loss } \\
Present & absent
\end{tabular} & $\begin{array}{l}4 \\
250\end{array}$ & $\begin{array}{r}1.6 \\
98.4\end{array}$ & $\begin{array}{l}3 \\
66\end{array}$ & $\begin{array}{l}75.0 \\
26.4\end{array}$ & 0.057 \\
\hline $\begin{array}{c}\text { Loss of appetite } \\
\text { Present } \\
\text { Absent }\end{array}$ & $\begin{array}{l}9 \\
245\end{array}$ & $\begin{array}{r}3.6 \\
96.4\end{array}$ & $\begin{array}{l}6 \\
63\end{array}$ & $\begin{array}{l}66.9 \\
25.7\end{array}$ & 0.012 \\
\hline Heart burn & $\begin{array}{l}154 \\
100\end{array}$ & $\begin{array}{l}60.6 \\
39.4\end{array}$ & $\begin{array}{l}46 \\
23\end{array}$ & $\begin{array}{l}29.8 \\
23.0\end{array}$ & 0.057 \\
\hline $\begin{array}{r}\text { Regurgitation } \\
\text { present } \\
\text { absent }\end{array}$ & $\begin{array}{l}12 \\
242\end{array}$ & $\begin{array}{r}4.7 \\
95.3\end{array}$ & $\begin{array}{l}4 \\
65\end{array}$ & $\begin{array}{l}33.3 \\
26.9\end{array}$ & 0.218 \\
\hline Vomiting & $\begin{array}{r}72 \\
182\end{array}$ & $\begin{array}{l}28.3 \\
71.7\end{array}$ & $\begin{array}{l}17 \\
52\end{array}$ & $\begin{array}{l}23.6 \\
28.6\end{array}$ & 0.092 \\
\hline Diarrhea & $\begin{array}{l}18 \\
236\end{array}$ & $\begin{array}{r}7.1 \\
92.9\end{array}$ & $\begin{array}{l}5 \\
64\end{array}$ & $\begin{array}{l}27.8 \\
27.1\end{array}$ & 0.563 \\
\hline
\end{tabular}


Thi-Qar Medical Journal (TQMJ): Vol (11) No (1)2016 utjmed@utq.edu.iq

\begin{tabular}{|c|c|c|c|c|c|}
\hline Absent & & & & & \\
\hline $\begin{array}{r}\text { Constipation } \\
\text { present } \\
\text { Absent }\end{array}$ & $\begin{array}{l}39 \\
215\end{array}$ & $\begin{array}{l}15.4 \\
84.6\end{array}$ & $\begin{array}{l}11 \\
58\end{array}$ & $\begin{array}{l}28.2 \\
27.0\end{array}$ & 0.151 \\
\hline Distension & $\begin{array}{l}61 \\
193\end{array}$ & $\begin{array}{l}24.0 \\
76.0\end{array}$ & $\begin{array}{l}19 \\
50\end{array}$ & $\begin{array}{l}31.1 \\
25.9\end{array}$ & 0.093 \\
\hline Smoking & $\begin{array}{l}41 \\
213\end{array}$ & $\begin{array}{l}16.1 \\
83.9\end{array}$ & $\begin{array}{c}11 \\
58\end{array}$ & $\begin{array}{l}26.8 \\
27.2\end{array}$ & 0.563 \\
\hline NSAID & $\begin{array}{l}17 \\
237\end{array}$ & $\begin{array}{r}6.7 \\
93.3\end{array}$ & $\begin{array}{l}5 \\
64\end{array}$ & $\begin{array}{l}29.4 \\
27.0\end{array}$ & 0.211 \\
\hline $\begin{array}{r}\text { Corticosteroids } \\
\text { present } \\
\text { Absent }\end{array}$ & $\begin{array}{l}1 \\
253\end{array}$ & $\begin{array}{r}0.4 \\
99.6\end{array}$ & $\begin{array}{l}1 \\
68\end{array}$ & $\begin{array}{r}100.0 \\
26.9\end{array}$ & 0.272 \\
\hline Alcohol drinking & $\begin{array}{l}2 \\
252\end{array}$ & $\begin{array}{r}0.8 \\
99.2\end{array}$ & $\begin{array}{c}0 \\
69\end{array}$ & $\begin{array}{r}\mathbf{0 . 0} \\
27.4\end{array}$ & 0.530 \\
\hline $\begin{array}{r}\text { Ultrasound exam. } \\
\text { Positive } \\
\text { negative } \\
\text { Total } \\
\end{array}$ & $\begin{array}{l}7 \\
247 \\
254\end{array}$ & $\begin{array}{r}2.8 \\
97.2 \\
100.0\end{array}$ & $\begin{array}{l}2 \\
67 \\
69 \\
\end{array}$ & $\begin{array}{l}28.6 \\
27.5 \\
27.5\end{array}$ & 0.323 \\
\hline
\end{tabular}

*Based on Chi-squared or Fisher Exact Tests

Table (2) Logistic regression analysis to predict positivity of $\mathrm{H}$ pylori

\begin{tabular}{|c|c|c|c|c|c|c|}
\hline variables & B & S.E. & Wald & df & Sig. & Exp(B) \\
\hline Age & -.003 & .013 & .042 & 1 & .839 & .997 \\
\hline Gender & .045 & .308 & .021 & 1 & .885 & 1.046 \\
\hline
\end{tabular}

\begin{tabular}{|c|c|c|c|c|c|c|}
\hline Duration of epigastric pain & $\mathbf{. 1 0 8}$ & $\mathbf{. 0 5 2}$ & $\mathbf{4 . 3 5 1}$ & $\mathbf{1}$ & $\mathbf{. 0 3 7}$ & $\mathbf{1 . 1 1 4}$ \\
\hline Weight loss & 2.449 & 1.729 & 2.006 & 1 & .157 & 11.572 \\
\hline Loss of appetite & 1.870 & .781 & 5.738 & 1 & .017 & 6.489 \\
\hline regurgitation & -1.022 & 1.155 & .782 & 1 & .376 & .360 \\
\hline Heart burn & .293 & .319 & .847 & 1 & .357 & 1.341 \\
\hline vomiting & -.337 & .363 & .865 & 1 & .352 & .714 \\
\hline Abdominal distension & -.040 & .226 & .032 & 1 & .859 & .960 \\
\hline
\end{tabular}

Discussion This study suggests no significant

variation in the age between patients with 
(HPSA) positive groups \& (HPSA) negative groups \& apparently, the age was not predictive of the pattern of infectivity of H. pylori. Although there was some difference in frequency of positive stool test which was remarkable in all age groups (Table1) yet this difference was statistically not significant in the logistic regression analysis. This result is in agreement with a study conducted in Bangladesh $\left({ }^{12)}\right.$ but contradicts another study (13). which concluded that $H$ pylori was more common in children and the incidence was declining with age, which may signify some age predilection. Similarly, Chen $\mathrm{S}$ et al concluded that $H$ pylori incidence decreases with age. ${ }^{(14)}$ Conversely, a Welsh \&German study revealed increasing infection with advanced age. ${ }^{(15,16)}$ However, in neighboring countries as in Saudi Arabia, H. pylori infection is acquired in the early age and the risk of infection increases as the age increased ${ }^{(6)}$

However, our observations confound mostly to adult age groups (account for $>90 \%$ of studied patients) Table (1) and there was a limited extension to childhood age groups, this prejudice may explain the limited effect of age in this study or the variations with the over mentioned studies may reflect geographic, racial or urban- rural variations.

The present study did not reveal difference in the risk of $H$. pylori positivity in relation to gender. This result was similar to an Indian study which showed also no significant difference in this regard. (17) Another study published by de Maretel and Parsonnet (2009) concluded a true relationship of H. pylori and male gender ${ }^{(18)}$

Conversely, two other studies reported

an increased bacterial load in females suggested a significant female gender predilection to $H$ pylori infection. ${ }^{(19,20)}$ Our results may require further studies taking into account the role of social and cultural values or larger sample is required as well as assessing the sex hormone profile in the infected patients. We have clearly seen that no significant association existed between HPSA positivity and each of heart burn and regurgitation. These results were consistent with a study by Laine L et al (2002) who demonstrated also no relationship between $H$ pylori infection and gastroesophageal reflux disease $\left(^{21)}\right.$ yet other studies reported a controversial relationship in this regard ${ }^{(22)}$. However, we cannot exclude 


\section{Thi-Qar Medical Journal (TQMJ): Vol (11) No (1)2016 utjmed@utq.edu.iq}

such relationship perhaps because of lack in the precise assessment of symptoms like cough, asthma \& hoarseness of voice which sometimes a manifestations of gastroesophageal reflux

$$
\text { disease }^{(3)}
$$

Our study did not observe a significant

change in body weight among patients with

HPSA positive as compared to negative groups, but this result may not be true and was confounded by other weight influencing conditions like endocrine causes physical activity level and economic status. The result support previous results in a study in New York which reported no significant association between $H$. pylori and overweight ${ }^{(23)}$ but contradicts another study in the United Kingdom that showed increase in body weight after successful eradication of H. pylori. ${ }^{(24)}$ Evaluation of diarrhea in this study did not significantly reveal evidence of $H$. pylori infection but comparing this result with a German study in 2012 which hypothesized that colonization with $H$ pylori might protect from diarrhea ${ }^{(16)}$. Interestingly a recent study demonstrated remarkable association between diarrhea of irritable bowel syndrome and $\mathrm{H}$ pylori. ${ }^{(25)}$

At the present study, the duration of epigastric abdominal pain appeared to be a potential predictor of infectivity $(\mathrm{p}<0.05)$ and the duration of the pain was sharply recognized into two groups: a group of $\leq$ two weeks $(40.7 \%)$ and group of > two weeks (59.3\%). The duration of epigastric abdominal pain appeared to be related to the $H$ pylori pattern of infectivity. We conclude that persistency of epigastric pain of more than 2 likely a strong predictor of $H$ pylori weeks was infection. These results may be explained by several points among them is the early contraction of infection in early childhood especially in developing countries as in southern parts of Iraq and also the $\mathrm{H}$. pylori infection tend to run in a chronic course like chronic gastritis or peptic ulcer. Also, it is well-known that acute phase of the $\mathrm{H}$. pylori infection may last for about 2 weeks or less \&often asymptomatic \&after that become chronic (26, 27,28,29,30). Lastly, the prevalence of H. pylori \&atrophic gastritis is increased in elderly in some studies ${ }^{(30,31)}$ this point could aid the correlations of long duration of epigastric pain \& microorganism infectivity.

Pearce et al reported that is $H$. pylori almost certainly acquired from close contact with infected individual in early childhood and persists for decades to become a major risk factor for the development of gastrodeudinal diseases in early adult life. ${ }^{(27)}$ Similarly, it was reported that $H$ pylori infection was acquired in early childhood and continued contact would have been required for the establishment of real infection that can last lifelong. (28) Malaty in 2007 concluded that the infection was acquired since childhood and appeared in adulthood separated by a period of latency. ${ }^{(29)}$ 
Kataralis et al suggested that the

prevalence of $H$. pylori \&atrophic gastritis increased in elderly ${ }^{(30)}$, as we referred to before, where others stated that H. pylori infection is rarely observed as acute illness which is asymptomatic but commonly seen as chronic (atrophic or non atrophic gastritis). This explains why long duration is necessary to create these complications. ${ }^{(31)}$ In our study we concluded that loss of appetite was second predictor for H. pylori infectivity, this result is in agreement with a recent study ${ }^{(31)}$ which showed that the chronic gastritis could induce chronic suppression of ghrelin (appetite stimulating peptide). It is well known that chronic gastritis is often a common presentation of H. pylori infection. Adding to that, chronic gastritis is commonly associated with postprandial pain which consequently suppresses the appetite ${ }^{(32) .}$ To conclude, this study strongly supports the view that patients with epigastric abdominal pain for > two weeks and loss of appetite are very likely to have $\mathrm{H}$ pylori infection.

Acknowledgement

We acknowledge the contribution of Professor Omron S Habib, Department of Community Medicine, and Basrah College of Medicine. His advice and assistance in statistical analysis of the results and reviewing the final draft were valuable to bring this article to its final shape. 
1. Warren JR, Marshall BJ. Unidentified curved bacilli on gastric epithelium in active chronic gastritis. Lancet 1983; 1: 1273-1275.

2. Walker B, Colledge N, Ralston S, Penman I, Penman I, Lees C. Alimentary tract and pancreatic disease in: Penman I, Lee C, Davidson principles \& practice of internal medicine Elsevier 22ed, 2014, p851, 872.

3. Kupers E, Blaser M. Acid peptic disease in: Goldman L, Schafer A: Goldman's Cecil Textbook of Medicine 24th ed. 2012. P 887,513-514.

4. Hussen B, Qader S, Ahmed H, Ahmed S. The Prevalence of H pylori among University Students in Iraq. Indian Journal of Science and Technology 36340-37557-1-PB.

5. Parsonnet J, Shmuely H, Haggerty T. fecal and oral shedding of Helicobacter pylori from Healthy infected adults. JAMA 1999; 282(23):2240-2245.

6. Khan M, Ghazi H. Helicobacter pylori infection in asymptomatic subjects in Makkah, Saudi Arabia. Journal of Pakistan Medical Association 2007; 57(3): 114-117.

7. Özaydın A, the geographic variance of Helicobacter pylori. EMJ Gastroenterol. 2014; 3: 94-102.

8. Shimoyama T. Stool antigen tests for the management of Helicobacter pylori infection. World J Gastroenterol. 2013; 19(45): 8188-8191.

9. Walsh T, Attiah E, Long D, Kasper D, Jamesson J, Fauci A. Hauser S Et al. Eating Disorders in: Harrison's principles of internal medicine. McGraw Hill Medical. 18th Edition 2012. P. 636.

10. Talley NJ, O' Connor S. Clinical Examination. A systematic guide to physical diagnosis $.6^{\text {th }}$ edition Elsevier Australia ., 2012.P 146

11. Lennon A, Goggins M. Disorders of the small and large intestine. The Johns Hopkins Internal Medicine Board Review. Johns Hopkins, 4thed 2012, p.213, 218.

12. Lee CS, Kim D, jung CW, Park jy. Prevalence of Helicobacter pylori in Bangladesh: Rapid urease test. The ORION Medical Journal 2003;16: 104-105

13. Rowland M, Daly S, Vaughan M, Higgins A, Bourke B, Drumm B. Age specific for Helicobacter pylori. Gastroenterology 2006 130(1); 65.

14. Chen S, Ying L, Kong M, Zhang Y, Li Y. Chen S et al. The Prevalence of Helicobacter pylori Infection Decreases with Older Age in Atrophic Gastritis Hindawi PublishingCorporation. Gastroenterology Research and Practice 2013; (2013) 3.

15. Sitas F, Forman D, Yarnell J, Burr M, Elwood P, Pedley S, Marks K. Helicobacter pylori in relation to age and social class in a population of Welsh men. Gut 1991;32: 25-28.

16. Bode G, Rothenbacher D, Brenner H. Helicobacter pylori colonization and diarrhoeal illness: results of a population-based cross-sectional study in adults. European Journal of Epidemiology 2002, 17:823-827.

17. Adlekha s, Chandha T, Krishnan P, Sumangala B. Prevalence of Helicobacter Pylori Infection Among Patients Undergoing Upper Gastrointestinal Endoscopy in a Medical College Hospital in Kerala, India Ann Med Health Sci Res. 2013;3(4): 559-563. 
18. e Martel C, Parsonnet J. Helicobacter pylori and gender: a meta-analysis of population based prevalence surveys. Dig Dis Sci 2006;15(12) :2292-301.

19. Moshkowitz M, Horowitz N, Beit-Or A, Halpern Z, Santo E; Gender-associated differences in urea breath test for Helicobacter pylori infection referrals and results among dyspeptic patients. World J Gastrointest Pathophysiol 2012; 15(3):80-88.

20. Ohtani M, Garcia A, Rogers A, Ge Z, Taylor N, Xu S. Protective role of 17 betas - estradiol against the development of Helicobacter pylori-induced gastric cancer in INS-GAS mice. Carcinogenesis 2007; 28(12):2597-2604.

21. Laine L, Sugg J. Effect of Helicobacter pylori eradication on development of erosive esophagitis and gastroesophageal reflux disease symptoms: a post hoc analysis of eight double blind prospective studies. Am J Gastroenterol 2002; 97: 2992-7.

22. Falk GW. The possible role of Helicobacter pylori in GERD. Semin Gastrointest Dis. 2001 12(3):186-95.

23. Cho I, Blaser MJ, Francois F, Mathew JP, Ye XY, Goldberg JD, Bini EJ. Helicobacter pylori and Overweight Status in the United States: Data from the Third National Health and Nutrition Examination Survey. Am J Epidemiol. 2005; 162(6):579-84.

24. Nwokolo CU, Freshwater DA, O'Hare P, Randeva HS. Plasma ghrelin following cure of Helicobacter pylori. Gut 2003; 52(5):637-640.

25. Yakoob J, Abbas Z, Naz S, Islam M, Jafri W. Virulence markers of Helicobacter pylori in patients with diarrhoea-dominant irritable bowel syndrome. Br J Biomed Sci. 2012; 69(1):610.

26. Brooks GF, Carroll KC, Butel JS, Morse SA, Mietzner TA. Jawetz, Melnick, and Adelberg's Medical Microbiology Twenty-Sixth Edition.2013. Chapter 17 Pp 261-262.

27. Pearce M, Campbell D, Mann K, Parker L, Thomas J. Deprivation, timing of preschool infections and H. pylori seropositivity at age 49-51 years: the Newcastle thousand families birth cohort. BMC Infectious Diseases, 2013; 13:422.

28. Salih BA. Helicobacter pylori Infection in Developing Countries: The Burden for How Long? The Saudi Journal of Gastroenterology 2009; 15:.201-207.

29. 29. Malaty H. Epidemiology of Helicobacter pylori infection Best Pract Rest Clin Gastoenterolo .2007; 21 (2): 205-214.

30. Katelaris P, Seow F, Lin B , Napoli j, Ngu M , and Jones D: Effect of age, Helicobacter pylori infection, and gastritis with atrophy on serum gastrin and gastric acid secretion in healthy men. Gut.1993; 34(8):1032-1037.

31. Francis D gastritis in: Hauser S, Pardi D, Poterucha J. The Mayo Clinic Gastroenterology and Hepatology Board Review myoclinic scientefic press 2008 p32, 71

32. Vo H, Goli S, Gill R, Anderson V, Stefanov D, Xu J: Inverse relation between Helicobacter pylori Colonization and obesity in cohort of inner city children, Helicobacter. 2015; 20(1):648. 
التتبؤ بعدوى الجرثومة المَعَدِيَّة الحلزونية باستخدام فحص مستضدات البراز في قضاء القرنة

هدف الدراسة: تحديد تتبئ العدوى الجرثومة المَعَدية الحلزونية عن طريق اختبار مستضدات البراز وارتباطها مع الام البطن الثرسوفيه والأعراض المعدية المعوية الأخرى.

المرضى وطرائق العمل: مرضى من القرنة قدموا الى العيادة الخاصة يعانون من ألم البطن الثرسوفي تم فحص كل واحد منهم عبر اختبار مستضدات البراز للجرثومة المعدية الحلزونية، بعد تقييم الاسباب الأخرى لألام البطن وأجري تحليل البيانات باستخدام برنامج اس بي اس اس النسخة 0 1.

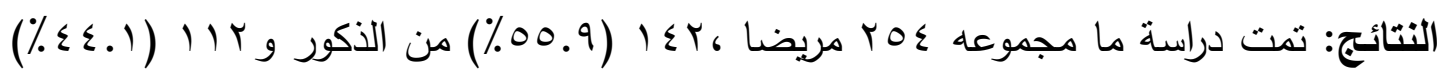
من الاناث وكان فحص مستضدات البراز للجرثومه المعدية الحلزونية ايجابيا في 79

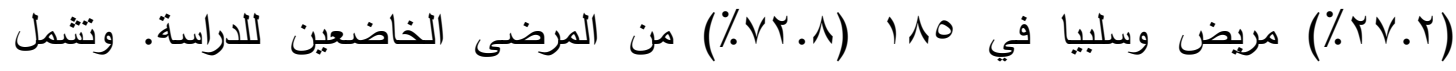
الأعراض المعدية المعوية التي لوحظت كل من، فقدان الوزن، فقدان الثهية (؟.ب٪) ، حرقة

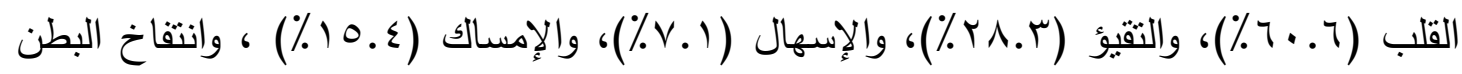




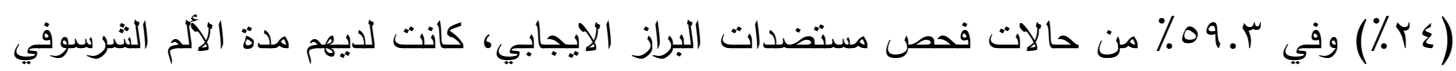

أكثر من أسبوعين.

الاستتتاجات: أثنار تحليل الانحدار اللوجستي الى ان ألم البطن الثرسوفي لأكثر من أسبوعين وفقدان الثهية ينبئان بقوة عن الاصابة بالبكنيريا المعدية الحلزونية. 